Sir - I read with interest the account of the meeting of the international board of advisers for the proposed European Centre for Infectious Diseases (ECID), held in Montpellier, France, in September (Nature 395, 106; 1998). Declan Butler's article raises a relevant point, which is the potential clash between the creation of a Europe-wide public health agency (focused on infectious diseases) and the reluctance of each nation to cede sovereignty over public health policy.

This question was discussed at length at the meeting. Dan Colley, head of the parasitic diseases division of the US Centers for Disease Control (CDC) and a member of the ECID board of advisers, stressed that a parallel with the CDC can be made. In the United States, health policy is the responsibility of each state. The CDC acts only as a coordinator, an adviser and a central data collector. The ECID could play a similar role in Europe, with health policy remaining under the sovereignty of each nation and the ECID providing complementary overall coordination.

The centre would build upon the many structures and initiatives that exist in Europe at national and international levels. However, it would create more efficient coordination at a global scale. This action should be extended to Eastern Europe and the former Soviet Union.

At the Montpellier meeting, a wall structure - where experts involved in research, surveillance and control of infectious diseases, and in training, would be concentrated in the same place - was considered by most to be more attractive, synergistic and effective than a simple network. This view was supported by those representing developing countries, and it was agreed that the central structure should be complemented by outstations, either in Europe or in developing countries. It was also decided to extend the board of advisers to welcome epidemiologists and public health practitioners. A steering committee has been designated, with myself as coordinator. The board and committee will prepare a project plan within six months. Michel Tibayrenc

Centre d'Etudes sur le Polymorphisme des Micro-organismes,

UMR CNRS/ORSTOM 9926, ORSTOM, BP5045, 34032 Montpellier Cedex 1, France

e-mail:michel.tibayrenc@cepm.mpl.orstom.fr

\section{Argentinian science down but not out}

Sir - The letter from Marcelino Cereijido, an outstanding scientist, and my friend and former teacher, is misleading, damaging and insulting to Argentinian scientists (Nature 394, 314; 1998). No one would dispute the facts cited: scientists have been subject to that oppression and much more. But to adduce that all scientific activity in the country has to be dismissed is a dangerous non sequitur.

The economic difficulties engendered by privatization and the push for pseudo cooperation with industry are diseases not exclusive to Argentina. That the present and past governments have had little interest in science and higher education is also not unique to this country.

Cereijido reaches an extraordinary conclusion: that Argentinians trained in this country, which is supposedly "devoid of science", achieve instant excellence simply by going abroad. Those who remain are doing "research, not science".

There are two possible corollaries. The first is that those who return to Argentina to work in science are so stupefied by society that they can no longer distinguish between good and bad science. However, this ignores the successes of many who are working hard with poor facilities. The second is that all scientists were in complicity with the former military regime. This ignores the difficulties of those who survived, and those who returned during the dark days of the regime. Their successes can be judged by the recognition accorded to them by eminent scientists and organizations worldwide, as Cereijido admits.

Argentina is far from a paradise for science. Much more has to be done to generate more than a modest contribution in the present economic circumstances.

Cereijido imputes to Argentina an ideal that combines technology with theology. His fetish is misplaced.

\section{J. Raul Grigera}

(Director)

Instituto de Física de Líquidos y Sistemas Biológicos, University of La Plata and CONICET,

c.c. 565, 1900 La Plata, Argentina

\section{Time to take a healthier}

\section{view of history}

Sir - Ziauddin Sardar recalled Ottoman science, especially astronomy, under the title "Eclipsed no more"1. On behalf of Turkish physicians, the progeny of Ottoman hakims, I would like to point out Ottoman medicine, which has also been largely neglected for the same reasons indicated by Sardar.

Although medical practice in the Turkish part of the Ottoman world was closely related to that of nearby countries such as Persia, especially from the ninth to the fifteenth century, it also developed its own distinct features. However, medical works were written mostly in Arabic and Persian. Classical texts were taught throughout the many hospitals and schools established by the Ottoman sultans, where patients were freely treated with traditional drugs, diet, hygienic and other supportive methods such as music for psychiatric patients. From the eleventh century onwards, European medicine began to exert an influence in Turkish areas ${ }^{2,3}$.

It is hoped that the project on "scientific literature in the Ottoman period" "will shed light on this neglected area.

Ibrahim C. Haznedaroglu

Hacettepe University Medical School, Ankara, Turkey

1. Sardar, Z. Nature 394, 634 (1998).

2. Unver, S. Hamdard Med. Digest 3, 121-138 (1959).

3. Nasr, S. H. Islamic Science: an Illustrated Study (Insan Yayinlari, Istanbul, 1989).

\section{No rustling at Roslin}

Sir - Vandana Shiva has not only accused us in press reports and on her website of "stealing" and "patenting" the Indian Vechur breed of cattle but she says we are aiming at "total patriarchal control over reproduction" (Nature 394, 821; 1998)!

For the record, we at the Roslin Institute have never had any Vechur 'germplasm' (semen or embryos or even DNA), we have never worked on this breed or requested it, we have not applied for any patents relating to it, and none of our patents refers to Indian cattle breeds (this information is in the public domain and can be checked). I doubt anyway if a naturally occurring breed can be patented. We have never referred to the Vechur on our website and we have never received a letter from Moti Lal Madan of the Indian Council of Agricultural Research. We did, however, receive a request for information from Dr Sulochana, dean of Kerala Agricultural University (KAU), and I faxed him my full denial. Sosamma Iype of KAU has never been to Roslin, nor do we collaborate with KAU.

Grahame Bulfield

Roslin Institute, Roslin, Midlothian EH25 9PS, UK 